\title{
Pengaruh Media Pendidikan Gizi (Komik) terhadap Peningkatan Pengetahuan dan Perubahan Berat Badan pada Anak Sekolah Dasar dengan Obesitas
}

\author{
Arie Nugroho \\ Jurusan Gizi, Politeknik Kesehatan Tanjungkarang, Indonesia \\ Email: arienugroho@poltekkes-tjk.ac.id
}

\begin{abstract}
Effect of Nutrition Education Media (Comic) on Increasing Knowledge and Weight Change in Primary School Children With Obesity. School age is a time when children experience rapid growth. At this age of physical activity continues to increase such as play, exercise. Wrong eating habits in schoolchildren can lead to serious nutritional problems, such as obesity. Eating behavior such as consumption of junk food and fried is associated with the occurrence of obesity in school children. This study was to determine the effect of nutritional education media (comic) to increase knowledge and weight loss in elementary school children with obesity in the city of Bandar Lampung. This study included experiment research with quasi experiment design study, conducted in Bandar Lampung City Elementary School. Subjects in the case were obese primary school children who received nutritional media (comic) intervention. The number of subjects consisted of 31 cases and 31 controls. The variables observed included weight changes and changes in knowledge of data. Data analysis was done by independent t-test and pair t-test. There was the influence of nutrition media intervention (comic) to the score of knowledge was shown with $p$-value $=0,001$. Where the increase of knowledge score only in the treatment group that was from $10,96+1,99$ to $13,38+1,68$. While nutrition media intervention (comic) did not give effect to changes in obese child weight shown with a $p$-value that is 0,491 for treatment group and 0,725 for the control group. The nutritional media (comic) interventions can improve the knowledge score of obese primary school children but have no effect on changes in child weight. The intervention should be done more than 2 weeks to see directly effect of nutritional media (comic) intervention on weight change, we should involve the professional in making comics and experiment on the use of comics as a material of intervention to the same population.
\end{abstract}

Keywords: Knowledge, Obesity, Weight change

\begin{abstract}
Abstrak: Pengaruh Media Pendidikan Gizi (Komik) Terhadap Peningkatan Pengetahuan dan Perubahan Berat Badan pada Anak Sekolah Dasar dengan Obesitas. Usia sekolah merupakan masa dimana anak mengalami tumbuh kembang yang cepat. Pada usia ini aktifitas fisik terus meningkat seperti, bermain, berolahraga. Kebiasaan makan yang salah pada anak sekolah dapat mengakibatkan masalah gizi yang serius, seperti obesitas. Perilaku makan seperti, konsumsi junk food dan gorengan dikaitkan dengan terjadinya obesitas pada anak-anak sekolah. Penelitian ini bertujuan untuk mengetahui pengaruh media pendidikan gizi (komik) terhadap peningkatan pengetahuan dan penurunan berat badan pada anak sekolah dasar dengan obesitas di kota Bandar Lampung. Penelitian merupakan penelitian eksperimen dengan disain penelitian quasi experiment, yang dilakukan di SD Kota Bandar Lampung. Subjek yang dijadikan kasus adalah anak SD yang mengalami obesitas yang mendapat intervensi media gizi (komik). Jumlah subjek terdiri dari 31 kasus dan 31 kontrol. Variabel yang diamati meliputi perubahan berat badan, dan perubahan pengetahuan data. Analisis data dengan uji independent t-test dan pair t-test. Ada pengaruh intervensi media gizi (komik) terhadap skor pengetahuan ditunjukan dengan nilai $p=0,001$. Terjadi peningkatan skor pengetahuan hanya pada kelompok perlakuan yaitu dari 10,96+1,99 menjadi $13,38 \pm 1,68$. Sedangkan intervensi media gizi (komik) tidak memberikan pengaruh terhadap perubahan berat badan anak obesitas ditunjukan dengan nilai $p$ yaitu 0,491 untuk kelompok perlakuan dan 0,725 untuk kelompok kontrol. Intervensi media gizi (komik) dapat meningkatkan skor pengetahuan anak sekolah dasar obesitas, akan tetapi tidak memiliki pengaruh terhadap perubahan berat badan anak. Pemberian intervensi ada baiknya dilakukan lebih dari 2 minggu agar dapat melihat secara langsung pengaruh intervensi media gizi (komik) terhadap perubahan berat badan, sebaiknya melibatkan pihak profesional dalam pembuatan komik dan dilakukan uji coba penggunaan komik sebagai bahan intervensi ke populasi yang sama.
\end{abstract}

Kata kunci: Obesitas, Perubahan berat badan, Pengetahuan 
Anak usia sekolah mengalami tumbuh kembang yang cepat. Asupan gizi yang baik dari segi kuantitas maupun kualitas diperlukan agar tumbuh kembang anak dapat optimal. Pemberian gizi pada usia ini biasanya tidak berjalan secara sempurna, karena banyak faktor lingkungan sangat mempengaruhi perilaku makanannya (Mahan LK \& Escott-Stump S, 2008).

Pola makan yang tidak sehat dan tinggi kalori pada anak sekolah dapat mengakibatkan masalah gizi yang serius yaitu obesitas. Pada anak sekolah, kejadian kegemukan dan obesitas merupakan masalah serius karena akan berlanjut hingga usia dewasa serta merupakan faktor risiko terjadinya berbagai penyakit metabolik (Jukes $\mathrm{MCH}$ et al, 2008).

Kegemukan dan obesitas terjadi akibat asupan energi dan lemak lebih tinggi daripada energi yang dikeluarkan (kurangnya aktivitas fisik dan sedentary life style). Masalah ini sering dikaitkan dengan pola konsumsi kebiasaan makan dan perilaku baik dirumah maupun di sekolah. Perilaku makan seperti, konsumsi makanan jajanan dan junk food yang tinggi lemak dan tinggi kalori, terutama makanan jajanan yang digoreng ini sering terjadi. Selain itu makanan jajanan juga tidak mengenyangkan. Mungkin hal inilah yang dapat dikaitkan dengan terjadinya obesitas pada anak-anak sekolah (Judarwanto, W. 2006).

Faktor risiko yang paling berhubungan dengan obesitas pada anak usia 5-15 tahun adalah tingkat pendidikan anak (Sartika R.A.D, 2011). Untuk itu perlu dilakukan upaya pencegahan dan penanggulangan faktor risiko obesitas dengan menanamkan pendidikan gizi pada anak sejak usia dini. Pendidikan gizi ini dapat diberikan melalui penyuluhan, pemberian poster, leaflet atau booklet pada anak sekolah (Suhardjo, 2003, Machfoedz I \& Suryani S, 2007).

Hasil penelitian di Semarang tahun 2014 diperoleh bahwa terjadi peningkatan rata-rata pengetahuan gizi pada anak sekolah sebelum intervensi pendidikan gizi adalah $66,45 \pm 9,6 \%$, meningkat menjadi $71,61 \pm 9,3 \%$ setelah intervensi pendidikan gizi. Median sikap anak sekolah tentang gizi sebelum intervensi 70,31\% meningkat menjadi $73 \%$ setelah pendidikan gizi. Hasil tersebut menunjukkan bahwa pendidikan gizi meningkatkan pengetahuan dan sikap anak sekolah dasar tentang gizi (Nuryanto dkk, 2014).

Hasil Riset Kesehatan Dasar menunjukkan hasil bahwa secara nasional prevalensi kurus pada anak umur 5-12 tahun adalah 11,2 persen (menurut IMT/U). Sedangkan prevalensi BB lebih pada anak umur 5-12 tahun masih tinggi yaitu 18,8 persen, terdiri dari gemuk 10,8 persen dan sangat gemuk (obesitas) $8,8 \%$. Provinsi Lampung termasuk 15 Provinsi yang memiliki angka BB lebih diatas angka nasional (Kementerian Kesehatan RI, 2013).

Tujuan penelitian ini adalah mengetahui pengaruh media pendidikan gizi (komik) terhadap peningkatan pengetahuan dan penurunan berat badan pada anak sekolah dasar dengan obesitas.

\section{METODE}

Penelitian ini termasuk jenis penelitian experiment dengan desain penelitian quasi experimental, yang dilakukan di SDN 2 Rawa Laut, Kota Bandar Lampung. Penelitian menggunakan dua kelompok yaitu kelompok perlakuan adalah anak obesitas yang mendapatkan intervensi komik, kelompok kontrol adalah anak obesitas yang tidak mendapatkan intervensi komik. Pemberian intervensi dilakukan selama 2 bulan dimana setiap 2 minggu sekali ( 4 kali selama proses intervensi) dilakukan pendampingan pembahasan komik oleh tim peneliti dengan cara dikumpulkan di aula sekolah. Selanjutnya pada kedua kelompok dilakukan pengukuran pengetahuan dan berat badan sebelum dan setelah pemberian komik.

Pengolahan data hasil penelitian yang telah dikumpulkan dilakukan menggunakan bantuan komputer. Analisis dalam penelitian ini menggunakan independent $t$-test dan paired $t$ test.

\section{HASIL}

\section{Karakteristik Subjek Sebelum Penelitian}

Pada penelitian ini subjek yang diteliti sebanyak 62 anak yang terdiri dari 42 anak lakilaki $(67,7 \%)$ dan anak perempuan sebanyak 20 anak (32,3\%). Uji Chi square terhadap karakteristik jenis kelamin subjek menunjukkan tidak ada perbedaan yang bermakna antara kelompok perlakuan dan kelompok kontrol nilai $p=1,000$. Sedangkan rata-rata umur subjek pada kelompok perlakuan adalah $10,83 \pm 0,67$ bulan dan pada kelompok kontrol adalah 10,07 $\pm 0,55$ bulan. Berdasarkan uji Mann-whitney terhadap karakteristik umur subjek sebelum penelitian menunjukkan bahwa tidak ada perbedaan yang bermakna antara kelompok perlakuan dan kelompok kontrol nilai $p=0,517$. Karakteristik subjek dari dua kelompok tersebut dapat dilihat pada tabel 1 . 
Tabel 1. Karakteristik Subjek Sebelum Intervensi

\begin{tabular}{|c|c|c|c|c|c|}
\hline \multirow{2}{*}{$\begin{array}{c}\begin{array}{c}\text { Karakteristik } \\
\text { subjek }\end{array} \\
\end{array}$} & \multirow{2}{*}{\multicolumn{2}{|c|}{$\begin{array}{l}\text { Perlakuan } \\
\text { Mean } \pm \mathrm{SD}\end{array}$}} & \multirow{2}{*}{\multicolumn{2}{|c|}{$\begin{array}{c}\text { Kontrol } \\
\text { Mean } \pm \text { SD } \\
\end{array}$}} & \multirow{3}{*}{$\begin{array}{c}p- \\
\text { value }\end{array}$} \\
\hline & & & & & \\
\hline \multirow{3}{*}{$\begin{array}{l}\text { Jenis kelamin } \\
\text { Laki- Laki } \\
\text { perempuan }\end{array}$} & $\mathbf{n}$ & $\%$ & $\mathbf{n}$ & $\%$ & \\
\hline & 21 & 67,7 & 21 & 67,7 & \multirow[t]{2}{*}{$\underset{\mathrm{a}}{1,000}$} \\
\hline & 10 & 32,3 & 10 & 32,3 & \\
\hline $\begin{array}{l}\text { Umur (tahun, } \\
\text { bulan) }\end{array}$ & & $\begin{array}{r}10,83 \pm \\
0,67\end{array}$ & \multicolumn{2}{|c|}{$10,70 \pm 0,55$} & $\underset{\mathrm{b}}{0,517}$ \\
\hline Pengetahuan & & $\begin{array}{r}10,96 \pm \\
1,99\end{array}$ & \multicolumn{2}{|c|}{$11 \pm 2,04$} & $0,977^{\mathrm{b}}$ \\
\hline $\begin{array}{l}\text { Berat Badan } \\
(\mathrm{kg})\end{array}$ & & $\begin{array}{r}53,91 \pm \\
7,03\end{array}$ & \multicolumn{2}{|c|}{$50,93 \pm 8,05$} & $0,074^{\mathrm{b}}$ \\
\hline
\end{tabular}

Uji Mann-whitney terhadap pengetahuan dan uji terhadap berat badan menunjukkan tidak ada perbedaan yang bermakna antara kelompok perlakuan dan kelompok kontrol sebelum perlakuan diberikan dengan nilai $p$ berturut-turut $\mathrm{p}=0,977$, dan $\mathrm{p}=0,074$.

\section{Hasil Analisis Setelah Penelitian}

\section{a. Hasil Analisis terhadap Pengetahuan}

Hasil analisis dengan uji Mann-whitney menunjukkan bahwa terdapat perbedaan yang bermakna rata-rata nilai pengetahuan antara kelompok perlakuan dan kelompok kontrol setelah intervensi dengan media gizi (komik) nilai $p=0,037$. Rerata nilai pengetahuan setelah intervensi adalah $13,38 \pm 1,68$ pada kelompok perlakuan dan $11,12 \pm 2,15$ pada kelompok kontrol. Pemberian intervensi media gizi dalam bentuk komik berpengaruh terhadap peningkatan pengetahuan subjek dalam hal ini terkait dengan peningkatan rata-rata nilai pengetahuan pada kelompok perlakuan. Hasil analisis intervensi media gizi (komik) terhadap pengetahuan pada masing-masing kelompok setelah intervensi dapat dilihat pada tabel 2 .

Tabel 2. Analisis Intervensi Media Gizi (Komik) terhadap Pengetahuan pada Masing-Masing Kelompok Sebelum dan Setelah Intervensi

\begin{tabular}{clll}
\hline \multirow{2}{*}{ Variabel } & Perlakuan & Kontrol & \multirow{2}{*}{} \\
\cline { 2 - 3 } & Mean \pm SD & Mean \pm SD & \\
\hline Pengetahuan & & & \\
Sebelum & $10,96 \pm 1,99$ & $11,00 \pm 2,04$ & $0,977^{\mathrm{a}}$ \\
Setelah & $13,38 \pm 1,68$ & $11,12 \pm 2,15$ & $0,001^{\mathrm{a}}$ \\
\hline
\end{tabular}

aju Mann-whitney

\section{b. Perbedaan Skor Pengetahuan}

Hasil uji Wilcoxon pada skor pengetahuan sebelum dan setelah intervensi antara kelompok perlakuan dan kontrol diperoleh nilai $p=0,001$ pada kelompok perlakuan artinya terdapat perbedaan skor pengetahuan yang bermakna sebelum dan setelah intervensi hanya pada kelompok perlakuan.

Rerata skor pengetahuan sebelum intervensi yaitu $10,96 \pm 1,99$ pada kelompok perlakuan dan 11,00 $\pm 2,04$ pada kelompok kontrol, sedangkan rerata pengetahuan setelah intervensi yaitu $13,38 \pm 1,68$ pada kelompok perlakuan dan $11,12 \pm 2,15$ pada kelompok kontrol. Perbedaan skor pengetahuan sebelum dan setelah intervensi antara kelompok perlakuan dan kontrol disajikan dalam Tabel 3.

Tabel 3. Perbedaan Skor Pengetahuan pada Sebelum dan Setelah Intervensi

\begin{tabular}{crcrr}
\hline \multicolumn{1}{c}{ Variabel } & \multicolumn{2}{c}{ Perlakuan } & \multicolumn{2}{c}{ Kontrol } \\
\hline $\begin{array}{c}\text { Pengetahuan } \\
(\%)\end{array}$ & Mean $\pm \mathrm{SD}$ & \multicolumn{1}{c}{$p$} & Mean $\pm \mathrm{SD}$ & $p$ \\
\hline Sebelum & $10,96 \pm$ & 0,001 & $11,00 \pm$ & 0,726 \\
& 1,99 & $\mathrm{a}^{* * *}$ & 2,04 & $\mathrm{a}$ \\
Setelah & $13,38 \pm$ & & $11,12 \pm$ & \\
& 1,68 & & 2,15 & \\
\hline
\end{tabular}

${ }^{a}$ uji Wilcoxon

Hasil uji Wilcoxon pada kelompok perlakuan menunjukkan perbandingan pengetahuan sebelum dan setelah intervensi dimana terdapat 0 subjek dengan hasil skor pengetahuan lebih rendah daripada sebelum intervensi, 11 subjek tetap, dan 20 subjek mempunyai skor pengetahuan lebih baik dari pada sebelum intervensi. Hasil berbeda ditunjukan pada kelompok kasus, dimana pada kelompok kasus menunjukan bahwa terdapat 3 subjek yang memiliki skor pengetahuan lebih rendah daripada sebelum intervensi, 24 subjek dengan skor tetap dan hanya 4 subjek saja yang memiliki skor lebih baik dari pada sebelum pemberian intervensi media gizi (komik).

\section{c. Analisis Intervensi Media Gizi (Komik) terhadap Berat Badan pada Masing- masing Kelompok setelah Intervensi}

Hasil analisis dengan uji Mann-whitney menunjukkan bahwa tidak terdapat perbedaan yang bermakna berat badan antara kelompok perlakuan dan kelompok kontrol setelah intervensi dengan media gizi (komik) nilai $p=0,075$. Rerata berat badan setelah intervensi adalah $53,87 \pm 7,03 \mathrm{~kg}$ pada kelompok perlakuan 
dan 50,91 $\pm 8,68 \mathrm{~kg}$ pada kelompok kontrol. Pemberian intervensi media gizi dalam bentuk komik tidak berpengaruh terhadap perubahan berat badan subjek.

Hasil analisis intervensi media gizi (komik) terhadap perubahan berat badan pada masing-masing kelompok setelah intervensi dapat dilihat pada tabel 4 .

Tabel 4. Analisis Intervensi Media Gizi (Komik) terhadap Perubahan Berat Badan pada Masing-masing Kelompok Sebelum dan Setelah Intervensi

\begin{tabular}{llll}
\hline \multirow{2}{*}{ Variabel } & Perlakuan & Kontrol & \multirow{2}{*}{$\boldsymbol{p}$} \\
\cline { 2 - 3 } & Mean \pm SD & Mean \pm SD & \\
\hline Berat badan & & & \\
Sebelum & $53,91 \pm 7,03$ & $50,93 \pm 8,05$ & $0,074^{\mathrm{a}}$ \\
Setelah & $53,87 \pm 7,03$ & $50,91 \pm 8,68$ & $0,075^{\mathrm{a}}$ \\
\hline
\end{tabular}

aji Mann-Whitney

\section{d. Perbedaan Berat Badan pada Sebelum dan Setelah Intervensi Media Gizi (Komik) antara Kelompok Perlakuan dan Kontrol}

Hasil uji wilcoxon pada berat badan sebelum dan setelah intervensi antara kelompok perlakuan dan kontrol diperoleh nilai $\mathrm{p}$ berturutturut yaitu $p=0,491$ dan $p=0,725$ artinya tidak terdapat perbedaan berat badan yang bermakna sebelum dan setelah intervensi baik pada kelompok perlakuan dan kelompok kasus.

Rerata berat badan sebelum intervensi yaitu $53,91 \pm 7,03 \mathrm{~kg}$ pada kelompok perlakuan dan 50,93 $\pm 8,05 \mathrm{~kg}$ pada kelompok kontrol, sedangkan rerata berat badan setelah intervensi yaitu $53,87 \pm 7,03 \mathrm{~kg}$ pada kelompok perlakuan dan 50,91 $\pm 8,68 \mathrm{~kg}$ pada kelompok kontrol. Perbedaan berat badan sebelum dan setelah intervensi antara kelompok perlakuan dan kontrol disajikan dalam tabel 5.

Tabel 5. Perbedaan Perubahan Berat Badan pada Sebelum dan Setelah Intervensi

\begin{tabular}{|c|c|c|c|c|}
\hline Variabel & \multicolumn{2}{|c|}{ Perlakuan } & \multicolumn{2}{|c|}{ Kontrol } \\
\hline $\begin{array}{c}\text { Berat } \\
\text { badan }(\%)\end{array}$ & Mean $\pm \mathrm{SD}$ & $p$ & Mean $\pm \mathrm{SD}$ & $p$ \\
\hline $\begin{array}{l}\text { Sebelum } \\
\text { Setelah }\end{array}$ & $\begin{array}{l}53,91 \pm 7,03 \\
53,87 \pm 7,03\end{array}$ & $0,491^{\mathrm{a}}$ & $\begin{array}{l}50,93 \pm 8,05 \\
50,91 \pm 8,68\end{array}$ & 0,725 \\
\hline
\end{tabular}

Hasil uji pada kelompok perlakuan menunjukkan perbandingan berat badan sebelum dan setelah intervensi dimana terdapat 3 subjek mengalami penurunan berat badan dibanding sebelum intervensi, 24 subjek berat badan tetap, dan 4 subjek justru mengalami peningkatan berat badan.

Hasil yang sama ditunjukan pada kelompok kasus, dimana hasil uji menunjukan bahwa terdapat 4 subjek yang mengalami penurunan berat badan daripada sebelum intervensi, 23 subjek dengan berat badan tetap, serta ada 4 subjek juga yang bertambah berat badannya.

\section{PEMBAHASAN}

\section{Karakteristik Subjek}

Peningkatan skor pengetahuan dan perubahan berat badan dalam penelitian ini dipengaruhi juga oleh beberapa variabel yang berpotensi untuk mengganggu hasil penelitian. Variabel itu adalah karakteristik yang ada pada subjek yaitu jenis kelamin, umur, skor pengetahuan sebelum pemberian perlakuan dan pengukuran berat badan. Oleh karena itu sebelum pemberian intervensi media gizi (komik) pada kelompok perlakuan dan kelompok kontrol variabel tersebut turut diuji dengan harapan variabel variabel antar kedua kelompok tersebut homogen.

Berdasarkan uji yang dilakukan terhadap variabel karakteristik subjek (jenis kelamin, umur), skor pengetahuan dan berat badan ternyata seluruhnya menunjukkan tidak ada perbedaan yang bermakna secara statistik antara kelompok perlakuan dan kelompok kontrol. Berdasarkan hasil tersebut maka dapat disimpulkan bahwa variabel karakteristik subjek (jenis kelamin, umur), skor penelitian dan berat badan yang diidentifikasi berpotensi mengganggu hasil penelitian di awal penelitian ini telah dikontrol.

\section{Pengaruh Media Gizi (Komik) terhadap Pengetahuan}

Ada pengaruh pemberian media gizi (komik) pada kelompok perlakuan nilai $p=0,001$. Dimana terjadi peningkatan skor pengetahuan hanya pada kelompok perlakuan yaitu dari $10,96 \pm 1,99$ menjadi $13,38 \pm 1,68$. Hasil ini sesuai dengan penelitian lain yang menyatakan bahwa pemberian media gizi berupa poster dan buku saku pada anak sekolah dasar dapat meningkatkan pengetahuan gizi pada anak sekolah dasar di Kota Semarang, dimana terjadi peningkatan rata-rata pengetahuan sebelum intervensi adalah $66,45 \pm 9,6 \%$, meningkat menjadi $71,61 \pm 9,3 \%$ setelah intervensi pendidikan gizi (poster dan buku saku) (Nuryanto 
dkk, 2014).

Hasil ini sesuai dengan teori yang menyatakan bahwa semakin banyak panca indera yang digunakan pada saat pemaparan materi dalam hal ini penggunaan media gizi (komik), maka akan lebih banyak menimbulkan daya tarik serta minat siswa sehingga pesan yang disampaikan menjadi jauh lebih mudah diterima khususnya pada anak usia sekolah (Muliani Y, 2012).

Pengetahuan merupakan salah satu dari tiga komponen yang mempengaruhi perilaku manusia karena pengetahuan adalah hasil dari obyek tertentu dan sebagian besar pengetahuan manusia diperoleh melalui indera mata dan telinga. Pendidikan kesehatan merupakan salah satu proses untuk meningkatkan pengetahuan seseorang, pengetahuan dapat meningkat karena informasi dari orang lain, media massa elektronik seperti koran, leaflet, majalah, televisi dan radio (Notoatmodjo S, 2010).

Hasil penelitian ini sejalan dengan penelitian Widajanti di Kota Semarang terhadap 282 anak dengan metode true experimental yaitu terdapat peningkatan pengetahuan pada siswa SD yang diberi komik tentang keanekaragaman makanan jajanan dan keamanan makanan jajanan (Widajanti L dkk, 2009). Pengetahuan merupakan faktor tidak langsung yang mempengaruhi perilaku seseorang dalam hal ini perilaku gizi. Pendidikan gizi memiliki tujuan untuk mempengaruhi perilaku konsumsi pangan menuju perilaku yang lebih baik, yang diawali dengan pemberian informasi untuk meningkatkan pengetahuan anak untuk menimbulkan kesadaran dan menyebabkan perubahan perilaku. Sesuai dengan teori pendidikan dan perilaku kesehatan yang menyebutkan bahwa pendidikan kesehatan dalam waktu yang pendek (immediate impact) akan menghasilkan perubahan atau peningkatan pengetahuan masyarakat (Khomsan A, 2000, Notoatmodjo S, 2010).

Pendidikan gizi dianjurkan untuk dilakukan pada saat anak masih berusia dini dimana perilaku masih lebih mudah untuk dipengaruhi (Wulandari A, 2007). Usia enam sampai dengan empat belas tahun adalah usia yang memadai untuk anak mendapatkan pendidikan gizi, karena pada usia ini anak mulai matang secara seksual dan matang untuk belajar serta merupakan periode intelektual (Hapsari 2003). Dari rentang usia tersebut usia sebelas tahun merupakan usia yang paling tepat untuk mendapatkan pendidikan gizi dikarenakan pada usia tersebut anak berada dalam tahapan operasional formal, yaitu mampu untuk berpikir secara abstrak, menalar secara logis, dan menarik kesimpulan dari informasi yang tersedia (Patterson CJ, 2008).

Sebagian besar metode pendidikan gizi yang sering dilakukan adalah metode ceramah untuk meningkatkan pengetahuan gizi anak sekolah (Wulandari A, 2007). Pada metode ini penyuluh lebih dominan dalam memberikan materi, sedangkan responden lebih dominan mendengarkan. Metode ini lebih efisien dan sederhana tetapi sering kali responden cenderung pasif yang dapat menciptakan suasana pendidikan gizi yang monoton dan menyebabkan kebosanan. Hasil uji Wilcoxon pada penelitian ini diperoleh bahwa pada kelompok perlakuan dua puluh subjek mempunyai skor pengetahuan lebih baik dari pada sebelum intervensi media gizi (komik), sedangkan pada kelompok kasus hanya empat subjek saja yang memiliki skor lebih baik dari pada sebelum pemberian intervensi media gizi (komik). Hasil penelitian (Hamida K, 2012) juga menunjukkan hasil serupa bahwa peningkatan pengetahuan melalui media komik lebih baik dibandingkan metode penyuluhan. Penelitian ini menunjukkan bahwa media berperan dalam peningkatan pengetahuan. Fungsi media dalam pendidikan adalah sebagai alat peraga untuk menyampaikan informasi atau pesan-pesan tentang kesehatan (Notoatmodjo, 2010).

Tampilan buku komik dianggap lebih menarik dibandingkan buku pelajaran pada umumnya, sehingga tingkat keberhasilan penggunaan komik ini lebih tinggi dalam merubah pengetahuan dan sikap anak SD. Hasil penelitian yang bermakna akan dapat membantu anak SD secara mandiri meningkatkan pengetahuan dan sikap anak SD (Widajanti L dkk, 2009). Pada penelitian ini diharapkan anak SD dapat dengan mudah memahami tentang obesitas terkait penyebab, akibat dan pedoman gizi seimbang dalam rangka menangani masalah obesitas pada anak SD melalui media gizi (komik).

\section{Perubahan Berat Badan pada Kelompok Perlakuan dan Kelompok Kontrol setelah Intervensi}

Hasil uji Wilcoxon diperoleh nilai $p$ berturut-turut yaitu 0,491 untuk kelompok perlakuan dan 0,725 untuk kelompok kontrol. Sehingga dapat disimpulkan bahwa tidak ada pengaruh pemberian media gizi (komik) terhadap perubahan berat badan, baik pada kelompok perlakuan dan kelompok kontrol. Tidak ada perbedaan perubahan berat badan pada kedua kelompok setelah pemberian intervensi media gizi (komik). 
Hasil ini sesuai dengan penelitan yang menyatakan bahwa perubahan berat badan pada anak obesitas lebih dipengaruhi dari peningkatan aktivitas fisik dan perilaku gizi seimbang dibandingkan pemberian pengetahuan gizi, sehingga intervensi berupa peningkatan aktivitas fisik dapat lebih memberikan efek positif terhadap perubahan berat badan bagi anak obesitas (Widajanti, 2009; Dewantari dkk, 2011).

Selain itu hasil penelitian (Sartika, 2011) menyatakan bahwa faktor keturunan merupakan faktor penting terjadinya kelebihan berat badan/ obesitas pada anak usia 5 s/d 15 tahun. Kegemukan dalam keluarga dan orang tua merupakan faktor risiko terjadinya kegemukan pada anak (Shaltin S \& Philip M., 2003). Menurut Farooqi (2005), faktor genetik memiliki kontribusi terhadap kegemukan anak sebesar 40$70 \%$, namun faktor lingkungan tetap menjadi sorotan sebagai penyebab kegemukan. Meskipun seseorang memiliki faktor genetik, namun jika tidak ada pencetus dari faktor lingkungan maka tidak sampai mengalami kelebihan berat badan. Bila kedua orang tuanya kegemukan, sekitar $80 \%$ anaknya menjadi kegemukan. Bila salah satu orang tua kegemukan maka risiko kegemukan anak menjadi $40 \%$ dan bila kedua orang tuanya tidak kegemukan maka risiko kegemukan anak menjadi 14\% (Sjarif D, 2002).

Sehingga disarankan untuk pelaksanaan program intervensi kesehatan masyarakat sebaiknya ditujukan pada keluarga dan determinan sosial (termasuk sekolah) yang difokuskan pada perubahan gaya hidup seperti membiasakan untuk tidak terlalu banyak mengonsumsi makanan tinggi kalori dan gula, serta peningkatan aktivitas fisik (Sartika, 2011). Disarankan untuk penelitian selanjutnya dapat diberikan intervensi berupa peningkatan aktivitas fisik bagi anak-anak yang obesitas.

Terbentuknya perilaku juga dipengaruhi oleh lingkungan, salah satunya adalah dukungan sosial (Contento IR, 2008). Dalam hal ini dukungan yang paling berpengaruh selain keluarga adalah sekolah (Aprilia BA., 2011). Pengaruh teman sebaya merupakan faktor sosial yang juga mampu memengaruhi pemilihan makanan jajanan (Taylor JP et al, 2005) yang berhubungan langsung terhadap asupan energi anak.

Dalam prosesnya, perubahan pengetahuan itupun akan diikuti dengan perubahan niat dan pada akhirnya akan mampu mengubah perilaku membentuk suatu perilaku baru yang lebih baik sesuai tujuan awal pemberian pendidikan gizi (Contento IR, 2008). Dalam hal ini outcome yang diharapkan adalah perubahan berat badan. Oleh karena itu penelitian ini dilakukan di SDN 2 Rawa Laut dengan harapan kelompok perlakuan yang bertambah pengetahuannya dapat mempengaruhi sikap dan perilaku menuju perilaku yang berpegang pada pedoman gizi seimbang dimana salah satu pilar gizi seimbang adalah aktivitas fisik secara teratur, sehingga kelompok perlakuan dapat mengalami perubahan berat badan.

Ketidaktahuan akan gizi yang baik pada anak ataupun orang tua menyebabkan anak sekolah sering berperilaku salah dalam mengonsumsi zat gizi (Devi, 2012). Beberapa penelitian sebelumnya menunjukkan bahwa pendidikan gizi sangat efektif untuk merubah dan meningkatkan pengetahuan dan sikap anak terhadap makanan, akan tetapi kurang efektif dalam mengubah perilaku dalam hal ini praktik makan (Zulaekah, 2012).

\section{SIMPULAN}

Hasil penelitian menunjukkan bahwa Intervensi media gizi (komik) dapat meningkatkan skor pengetahuan anak sekolah dasar obesitas, akan tetapi tidak memiliki pengaruh terhadap perubahan berat badan anak.

\section{SARAN}

Pemberian intervensi ada baiknya dilakukan lebih dari 2 minggu agar dapat melihat secara langsung pengaruh intervensi media gizi (komik) terhadap perubahan berat badan, sebaiknya melibatkan pihak profesional dalam pembuatan komik dan dilakukan uji coba penggunaan komik sebagai bahan intervensi ke populasi yang sama.

\section{DAFTAR PUSTAKA}

Aprilia BA. Faktor yang Berhubungan dengan Pemilihan Makanan Jajanan pada Anak

Sekolah Dasar. 2011. [Skripsi]. Semarang: Universitas Diponegoro. 
http://eprints.undip.ac.id.

Contento IR. 2008. Nutrition Education: Linking Research, Theory, and Practice. Asia Pacific Journal of Clinical Nutrition. 17 (1): $176-179$.

Dewantari dkk. 2011. Perbedaan perubahan berat badan berdasarkan frekuensi senam aerobik. Jurnal Ilmu Gizi, Volume 2 Nomor 1 Febuari:66-73.

Devi, Nirmala. 2012. Gizi Anak Sekolah. Kompas Media Nusantara. Jakarta

Farooqi I. 2005. Genetic and hereditary aspects of childhood obesity. Best Practice and Research Clinical Endocrinology and Metabolism.19: 359-74.

Hamida K, Siti Z, Mutalazimah. 2012. Efektivitas Penyuluhan Gizi Dengan Media Komik Untuk Meningkatkan Pengetahuan Tentang Keamanan Makanan Jajanan Sekolah Siswa Sekolah Dasar. Jurnal Kesehatan Masyarakat, Vol. 8, No. $1 ; 72-79$.

Hapsari, I. I. 2003. Efektifitas Ludo Word Game terhadap Peningkatan Kosakata Bahasa Inggris pada Anak Studi Kasus pada Siswa Kelas IV SD Muhammadiyah 4 Pucang. [Skripsi]. Surabaya: Fakultas Psikologi Universitas Airlangga,5(1), 1-16. http://journal.unair.ac.id/ article_2911_ media8_category10.html.

Judarwanto, W. 2006. Antisipasi Perilaku Makan Anak Sekolah. http://www.pdpersi. co.id/ pdpersi/news/artikel.

Jukes MCH, Drake LJ dan Bundy DAP. 2008. School Health, Nutrition and Education For All Levelling the Playing Field. CABI Internasional. USA. p.3-29

Kementerian Kesehatan RI. 2013. Riset Kesehatan Dasar 2013. Laporan Nasional.

Khomsan A. 2000. Teknik Pengukuran Pengetahuan Gizi. Bogor: Fakultas Ekologi Manusia Institut Pertanian Bogor.

Machfoedz I \& Suryani S. 2007. Pendidikan Kesehatan bagian dari Promosi Kesehatan. Yogyakarta: Fitramaya. p.8-73

Mahan LK, Escott-Stump S. 2008. Krause's Food \& Nutrition Therapy. 12th edition. Saunders Elsevier. p.234 - 236

Muliani Y. 2012. Hubungan Antara Promosi
Keamanan Pangan Dengan Sikap Memilih Pangan Jajanan Anak Sekolah Yang Aman. [Tesis]. Jakarta: Program Pasca Sarjana Departemen Ilmu Komunikasi Fakultas Ilmu Sosial dan Ilmu Politik Universitas Indonesia. http://lontar.ui.ac.id (Diakses pada 26 Mei 2013).

Nuryanto, N., Pramono, A., Puruhita, N., \& Muis, S. F. 2014. Pengaruh pendidikan gizi terhadap pengetahuan dan sikap tentang gizi anak Sekolah Dasar. Jurnal Gizi Indonesia, 3(1), 32-36.

Notoatmojo S. 2010. Metodologi Penelitian Kesehatan. Rineka Cipta.

Patterson CJ. Child Development. New York: McGraw Hill; 2008.

Sartika, Ratu Ayu Dewi. 2011. Prevalensi dan Determinan Kelebihan Berat Badan dan Kegemukan pada Anak Berusia 5-15 Tahun. Jurnal Kesehatan Masyarakat Nasional, Vol. 5, No. 6.

Shaltin S, Philip M. 2003. Role of obesity and leptin in the pubertal process and pubertal growth a review. International Journal of Obesity. 27 (8): 869-74.

Sjarif, D. R. 2002. Obesitas pada anak dan permasalahannya. Balai Penerbit FKUI, Jakarta.

Suhardjo. 2003. Berbagai Cara Pendidikan Gizi. Jakarta: Bumi Aksara.

Taylor JP, Evers S, McKenna M. Determinants of Healthy Eating in Children and Youth. 2005. Canadian Journal of Public Health. 96 (3): 20-26.

Widajanti L, Chriswardani S, dan Anung S. 2009. Pengaruh Komik Makanan Jajanan Sehat dan Bergizi untuk Meningkatkan Pengetahuan dan Sikap Anak Sekolah Dasar. The Indonesian Journal of Public Health. Vol. 6, No. 1; 19 - 23.

Wulandari A. 2007. Peningkatan Pengetahuan Gizi Pada Anak Sekolah dengan Metode Ceramah dan Role Play. [Skripsi]. Semarang: Fakultas Kedokteran, Universitas Diponegoro. http://eprints.undip.ac.id

Zulaekah S. 2012. Pendidikan Gizi dengan Media Booklet terhadap Pengetahuan Gizi. Jurnal Kesehatan Masyarakat, 7(2), 127- 133. 